\title{
Leituras plurais, escritas equilibristas
}

https://doi.org/10.34112/2317-0972a2019v37n77pg-11

Anderson Ricardo Trevisan ${ }^{1}$

Renata Aliaga ${ }^{2}$

Leituras Plurais, Escritas Equilibristas É o tema ESCOlHido para o $22^{\circ}$ Congresso de Leitura do Brasil, que será realizado no mês de julho de 2020. Por meio dele, a Associação de Leitura do Brasil deseja fomentar discussões e reflexões acerca das Leituras Plurais que nascem das Escritas Equilibristas, malabaristicamente manejadas em meio a tantas adversidades. Assim, já adiantamos nosso convite àqueles que desejarem dialogar e compartilhar conosco suas experiências e pesquisas com leitura e educação, em movimentos de criação nas interfaces palavra, imagem, corpo e som. Em tempos de corda bamba, $\mathrm{o} 22^{\circ} \mathrm{COLE}$ abre espaço à esperança equilibrista, que dança e traz o apelo de que inevitavelmente temos (e devemos) que continuar.

Nesta edição de $n^{\circ} 77$ da revista, apresentamos o dossiê Raymond Williams: leituras, organizado por Alexandro Henrique Paixão a partir do VI Colóquio de Pesquisa Educação e História Cultural - Por que ler Raymond Williams no século XXI? Crises, dilemas e desafios teórico-práticos na contemporaneidade, realizado pelo Laboratório de Estudos de Cultura, História, Educação e Sociologia (LECHES FE/Unicamp) e pelo Laboratório de Investigação em Sociologia da Arte (LAISA - FE/Unicamp), ambos da Faculdade de Educação da Unicamp. Cada um dos

1. Universidade Estadual de Campinas, Campinas, SP, Brasil.

2. Instituto Federal de São Paulo, Campinas, SP, Brasil. 
artigos será gentilmente apresentado pelo professor Alexandro, a quem agradecemos de maneira muito especial - como também aos demais autores e autoras, por nos permitir compartilhar com nossos leitores os resultados dos trabalhos que vêm sendo realizados em torno dessa temática.

Na sequência, apresentamos o artigo "Imagem, sociedade e conhecimento: da história cultural à sociologia da arte", de Anderson Ricardo Trevisan, que dialoga com os artigos do dossiê ao discutir possibilidades de uso das imagens como caminho de construção do conhecimento. Tendo como ponto de partida a questão: "será possível conhecer uma sociedade lendo as imagens que ela cria?", o autor traz algumas discussões sistematizadas pela historiografia, tendo como referência Jacob Burckhardt e Johan Huizinga, passando pelos teóricos do Instituto Warburg, especialmente Panofsky e Gombrich, e finalizando com as proposições da Sociologia da Arte de Pierre Francastel.

Os demais artigos desta edição trazem como eixo de sua discussão a formação de leitores em sua interface com a escola, destacando a relevância da atuação dos professores como mediadores desse processo. No artigo "Ensinar a ler em diferentes áreas do conhecimento: o que pensam os professores sobre o ensino da compreensão leitora?", Pâmela Lopes Vicari e colaboradoras propõem uma discussão a respeito de como alguns professores pensam e ensinam a compreensão leitora em sala de aula, a partir de pesquisa realizada com professores de uma escola da rede municipal de Ensino Fundamental do interior do Rio Grande do Sul. Já em "Aula de leitura no contexto sociocultural do cordel", Linduarte Pereira Rodrigues e Rodrigo Nunes da Silva trazem uma discussão sobre o uso dos folhetos de cordel nas aulas de leitura, tendo em vista as tradições orais de transmissão cultural. $O$ texto caminha para uma reflexão sobre o papel do professor como agente e mediador de questões culturais através da leitura. No artigo "(Multi)letramento em um colégio público no Paraná: compreensão responsiva em atividades de leitura sobre postagens do Facebook", Bruno Ciavolella e Neiva Maria Jung apresentam os resultados de uma pesquisa-ação realizada com alunos do oitavo ano de uma escola pública no Paraná, que teve como objetivo investigar se e como a diversidade cultural e de linguagens é compreendida nos enunciados em práticas letradas escolares.

Por fim, encerramos nosso editorial com o poema Élévation, de Charles Baudelaire, como forma de prestar nossa homenagem ao Professor Joaquim Brasil Fontes Júnior, que nos deixou em julho deste ano. Sua longa trajetória acadêmica foi marcada por uma genialidade singular, que inspirou muitos de nós. Amigo e colaborador, Joaquim Brasil foi membro do corpo editorial desde as primeiras 
edições da revista Leitura: Teoria \& Prática e sempre esteve muito próximo dos esforços realizados por essa Associação.

Nossa sincera gratidão!

\section{ÉLÉVATION ${ }^{3}$}

Au-dessus des étangs, au-dessus des vallées,

Des montagnes, des bois, des nuages des mers,

Par delà le soleil, par delá les éthers,

Par delà les confins des spheres étoilées,

Mon esprit, tu te meus avec agilité,

Et, comme un bon nageur qui se pâme dans l'onde,

Tu sillones gaîment l'inmensité profonde

Avec une indicible et mâle volupté.

Envole-toi bien loin de ces miasmes morbides, Va te purifier dans l'air supérieur,

Et bois, comme une pure et divine liqueur,

Le feu clair qui remplit les espaces limpides.

Derrière les ennuis et les vastes chagrins

Qui chargent de leur poids l'existence brumeuse, Heureux celui qui peut d'une aile vigoureuse

Sélancer vers les champs lumineux et sereins;

Celui dont les pensers, comme des alouettes, Vers les cieux le matin prennent un libre essor, - Qui plane sur la vie, et comprend sans effort Le langage des fleurs et des choses muettes!

(BAUDELAIRE, 1942: 86)

\section{ELEVAÇÃ $O^{4}$}

Por sobre os pantanais, os vales orvalhados, As montanhas, os bosques, as nuvens, os mares, Para além do ígneo sol e do éter que há nos ares, Para além dos confins dos tetos estrelados,

Flutuas, meu espírito, ágil peregrino,

E, como um nadador que nas águas afunda, Sulcas alegremente a imensidão profunda Com um lascivo efluido gozo masculino.

Vai mais, vai mais além do lodo repelente, Vai te purificar onde o ar se faz mais fino, E bebe, qual licor translúcido e divino, O puro fogo que enche o espaço transparente.

Depois do tédio e dos desgostos e das penas Que gravam com seu peso a vida dolorosa, Feliz daquele a quem uma asa vigorosa Pode lançar às várzeas claras e serenas;

Aquele que, ao pensar, qual pássaro veloz, De manhã rumo aos céus liberto se distende, Que paira sobre a vida e sem esforço entende A linguagem da flor e das coisas sem voz!

3. BAUDELAIRE, C. Les fleurs du mal [préface: André Gide]. Rio de Janeiro: Librairie Victor/ Chantecler, 1942.

4. Rio de Janeiro: Nova Fronteira, 1985 